\title{
PROLEGOMENA IN PEDAGOGY OF INFORMAL EDUCATION
}

\author{
Dr. Tanya Zhelyazkova-Teya \\ Institute of Informal Innovation (Bulgaria)
}

\begin{abstract}
The article presents the foundations of the Pedagogy of Informal Education, created by the author during 12 years of research work in informal education. The object, the subject, the general scientific definition, the categorical apparatus, the prerequisites, the goals, the tasks, the principles, the laws, the approaches, the methods, the models of teaching, the components of the educational process, the sections and the pedagogical "family" of Pedagogy of informal education as transpedagogy are presented. The experience of general pedagogy and the existing special pedagogies is used, taking into account the specifics of informal education. Philosophical, general scientific and concrete scientific methods of theoretical and empirical research are applied.

Keywords: educational triad; formal education; non-formal education; informal education; Pedagogy of Informal Education; informal educators; Homo creabilis
\end{abstract}

\section{Introduction}

By the spring of 2020, as the insidious COVID-19 virus devastated cities, it had locked people in their homes and replaced reality with virtual reality. The agenda has been radically changed. A new life context was created, in which the following intertwined:

- official (formal) rules of conduct established by government bodies;

- non-formal online programs of suspended cultural institutions, museums, galleries, libraries, theaters, music and singing performers;

- the informal experience of each person in new unknown conditions of life.

The spheres of life from the "Wheel of Life Balance" (invented by Paul J. Mayer) have radically changed their meaning. And so it continues for the second year. And some life processes will remain forever changed.

The pandemic has made a great contribution to the development and expansion of the parameters of informal education:

- who is a sharp increase in subjects actively using informal education as a resource;

- what - an increase in the volume of most indicators of informal education; 
- where is the increase in territory - the whole world;

- when - continuously $24 / 7$;

- how - personalized and free access to all electronic resources on the network;

- why - the pandemic has changed the rules, and some have called it a "viral revolution" while we adhere to a state of "viral evolution".

The role of individual informal education in the form of personal life experience has turned out to be key not only now, but also in the future.

Here is the place to clarify that too often in the English literature informal means non-formal, when the three terms formal, informal and informal are not used simultaneously. This misleads many foreign authors and leads to incorrect scientific results even in dissertations. Our numerous publications on informal education fight against this tendency, always specifying the specific contents of the three terms.

Recognition of informal education is easier when it is considered as part of the „educational triad" 1 of formal, non-formal and informal education and the definition of the three components of the triad is carried out in accordance with common criteria that reveal integration and differentiation between them. Analyzing the relationship between formal, non-formal and informal education, author's definitions of the components of the educational triad are obtained.

Formal education: institutionalized, organized, systematized and limited in time and place education for the accumulation of knowledge, development of skills and the formation of competencies in a highly structured, programmed, planned and psycho-pedagogical process to achieve levels in the national qualifications framework of countries, which ends with a qualification document.

Non-formal education: institutionalized, organized, systematized and limited in time and place education for the additional accumulation of knowledge, development of skills and the formation of competencies in a structured, planned and teacher-guided process of supporting professional and personal development, which ends with a certificate of development of skills without qualification value.

Informal education: non-institutionalized, unorganized, unconstrained, unlimited, free, accessible, constant and widespread accumulation of knowledge, development of skills and the formation of competencies in the life process of people of different ages, supporting the process of their personal self-development and self-creation.

In the European context, informal learning has gained popularity in EU Member States through the recommendation on the validation of non-formal and informal learning (CR 2012).

The Bulgarian national normative context is characterized by the introduction in 2015 of the active consulting activity of the author of the term "informal 
learning" in the new Law on Preschool and School Education, and through it in the Law on Vocational Education and Training, as well as in The Employment Promotion Act.

Our research work on informal education for 12 years has unequivocally proven that informal education is a category with an integral meaning.

Implicit informal education (unintentionally): incidental, accidental, unconscious, unplanned, unintentional, unworked, unfocused, spontaneous, unsystematic, unregulated.

Procedural informal education (intentionally): expected, intentional, conscious, acquired, purposeful, self-directed, systemic, regulated.

Life-meaning informal education (substantially): real, targeted, conscious, planned, earned, expedient, meaningful, integrative, inevitable.

This structuring of informal education is due to the theoretical need to demonstrate its complexity and ambiguity, which often makes it difficult for researchers to define it in the traditional way. In fact, informal education manifests itself in its integrity and structural unity.

The idea of "informal self-pedagogy" appeared in the author's first philosophical dissertation "Understanding as a philosophical problem (in the context of informal education)" in 2009. Then the idea continued to be maintained and developed in seven articles from 2010 to 2019. Part of the pedagogical innovative process was stated "the creation of a Bulgarian model of informal pedagogy"2). On the agenda was the need for a new platform for learning in the informal age, and the knowledge, skills and competencies achieved through informal self-pedagogy to be validated in society ${ }^{3}$. The exceptional importance of informal pedagogy for solving a number of serious social problems of our time was emphasized ${ }^{4}$. Attention was drawn to the fact that it is necessary to create with common intellectual efforts "informal pedagogy" as a part of social pedagogy of great importance for the contribution of informal education in the building of the personality ${ }^{5}$. It was emphasized that the most important step in support of the new Homo creabilis (Zhelyazkova 2015) is the creation of informal pedagogy, which requires the simultaneous efforts of a wide range of professionals from different disciplines ${ }^{6}$. New educational trends at the beginning of the XXI century increasingly indicate a growing role of informal education in the training and education of people of all ages throughout life. This raises the question of the theoretical understanding of the future informal pedagogy ${ }^{7}$. In 2019, informal pedagogy was defined as historically the first type of pedagogy known to mankind ${ }^{8)}$.

Everything was prepared for the transformation that took place in 2020 in the concept of informal pedagogy. It became clear that the huge accumulated theoretical and experimental material cannot "work" in the construction of 
"informal pedagogy", because it is illogical for the informal to be a definition of pedagogy. But it is logically and theoretically justified to develop Pedagogy of informal education (PIE) as an independent new pedagogical discipline.

As a result of a historical review of pedagogical thought the prism of selfdevelopment and informal education of adults throughout life and research by other authors in the context of general pedagogy, the history of pedagogy and andragogy, we came to the conclusion that it is necessary to substantiate the PIE as a way to reveal the essential characteristics of informal education. The set of initial knowledge about PIE is presented in the results of this article.

\section{Methodology and methods of research}

During the research, the following philosophical, general scientific and specific scientific methods were used:

1. General theoretical methods and methods of theoretical research - analysis of bibliographic sources (dictionaries, reference books, scientific publications, regulatory documents), description, induction and deduction, analysis and synthesis, analogy, theoretical analysis, abstraction, ascent from the abstract to the concrete, classification, interpretation, modeling, heuristic methods for generating new ideas;

2. Methods of empirical research - observation, comparison, one's own teaching practice in different age groups and periods of time, methods of extracting knowledge and experience.

\section{Results}

PIE does not appear in an empty space. It summarizes the experience of mankind in different centuries to seek and find the most appropriate and effective ways to educate not only children and young people by preparing them for life, but also to improve the knowledge, skills and competencies of adults to adapt to the ever-changing catches of existence within a human life. For this reason, the literature sources used are of a wide range of time and those related to the language in which the PIE was originally created (2020) predominate, including basic knowledge of textbooks.

\section{Pedagogy of Informal Education (PIE)}

The object of PIE is informal education as a phenomenon of reality, which determines the development of the human individual in the process (Slastenin $2002,60)$ of his life.

The subject of PIE: "essential aspects of (informal) education associated with the daily processes of human growth and development" (Slastenin 2002, 58).

General scientific definition of PIE: A new direction in pedagogical science for studying the patterns of informal education as a pedagogical phenomenon. 
Categorical apparatus of PIE:

- The pedagogical process in PIE is a non-institutionalized, disorganized, unconstrained, unlimited, free, accessible, constant and ubiquitous action of an individual aimed at meeting personal needs. "Recognizing the pupil as a subject of the pedagogical process, humanistic pedagogy thereby affirms the priority of subject-subjective relations in its structure" (Slastenin 2002, 73).

- The pedagogical action in PIE - auto-pedagogy, autodidactics, selfinstruction manual, self-educator. "... Each person empirically acquires certain knowledge, establishes some dependencies between pedagogical phenomena" (Slastenin 2002, 58).

- The pedagogical interaction in PIE - with informal educators "in the process of everyday life" (Slastenin 2002, 63).

- The pedagogical impact in the PIE of people in the process of life - "the greatest influence on the personality is exerted by another personality, which is for us a reference and authoritative one" (Slastenin 2002, 123).

- The pedagogical influence in PIE of the living environment in general.

- The pedagogical attitude in PIE to oneself and the social environment.

- The Pedagogical activity in PIE is "a special type of ... (self) activity aimed at achieving goals" (Slastenin 2002, 73) personality. Autoactivity.

- The Pedagogical situation in PIE - every moment of a learning person life informally, including the situation of intersubjective value-semantic interaction; a situation of creative self-realization; the situation of experiencing a new experience; reflexive-evaluative situation (Okereshko 2015, 76 - 77). below).

- The content of education in PIE is inseparable from life (more details

- Educational tools in PIE - pedagogical (types, methods - in more detail below).

- Self-upbringing - "systematic and conscious human activity aimed at selfdevelopment and the formation of their basic culture" (Slastenin 2002, 128). Autoeducator.

- Self-study - the study of oneself. Autodidactics.

- Self-education is an independent activity of the individual "for the realization of the goals of (informal) education in the conditions of the (informal) pedagogical process" (Slastenin 2002, 74) "comprehensively and continuously in the process of life itself" (Slastenin 2002, 63). Autoteacher.

- Self-development is "a process that is aimed at overcoming contradictions in striving to achieve spiritual, physical and social harmony" of the personality (Slastenin 2002, 116). Self-conscious, continuous, multi-stage process of self-creation of a person in adulthood through life-meaning orientation and personal experience using the resources of informal education throughout life. Autoevolution (K. Tsiolkovsky). 
Prerequisites of PIE:

- Axiological - the intrinsic value of personal existence.

- Cultural - the importance of informal education for personal culture in the context of well-established cultural traditions.

- Anthropological - comprehensive knowledge of a person as a subject of informal education.

- Humanistic - a special value of a person in informal education personalization.

- Hermeneutic - comprehending human existence through informal education.

- Synergetic - personality as a self-organizing and self-developing system.

The purpose of PIE: pedagogical support of the process of accumulation of knowledge, development of skills and the formation of competencies in the process of life of people of different ages ${ }^{7}$, supporting the process of their personal self-development and self-creation. "The main social goal of adult education is to promote the lifelong personal development of a person, the progressive enrichment of his activity abilities, spiritual world and creative potential" (Slastenin 2000, 277).

Tasks of PIE:

1. Establish patterns of informal education.

2. To reveal trends in the development of informal education.

3 . Design pedagogical technologies of informal education.

4. Support informal education for everyone.

5. Prepare people for their role as informal educators.

Principles of PIE:

1. The principle of self-knowledge: "Know thyself" (The Ancient Greek aphorism).

2. The principle of personal significance (Andreev 2012, 201).

3. The principle of individual style (Andreev 2012, 202).

4. Do-it-yourself principle.

5. The principle of self-government - self-organization, self-control.

6 . The principle of non-interference in life and support on demand.

7. The principle of "self".

8. The principle is its own author (Homo creabilis).

9. The principle of innovation.

10. The principle of voluntariness.

11. The principle of electivity.

12. The principle of continuity.

The Laws of Informal Education in PIE

1. The law of self-identity.

2. The law of self-development through denial of denial. 
3. The law of transition of quantitative changes of personality into qualitative ones.

4. The law of unity and struggle of opposites of personality.

5. The law of the community of individuals (Docenko 2016, 155).

6. The law of independence (Docenko 2016, 156).

Approaches to PIE: contextual, personality-activity, competence-based, functional, sociocultural, andragogic, systemic, comparative (Nefedova 2017, 74), "approach to personality as a subject of the life path" (AbulhanovaSlavskaya 2018, 184).

Methods of PIE:

- Simulation methods.

- Heuristic-modeling methods - cognitive, creative, organizational activity (Hutorskoi 2003, $332-345$ ).

- Research methods, including trial and error.

- Productive and practical methods (including learning by doing and experiencing, mutual learning) (Makarenko 1983; Makarenko 1990).

Learning models in PIE - determined by preferred learning styles, established from empirical research on informal education (Zhelyazkova-Teya 2020; Indikatory obrazovanija):

- learners using digital resources (remote, online, mobile, audiovisual);

- learners under someone's guidance (experience of others - family, friends, colleagues, authority figures);

- learners through excursions (museums, cultural, historical, natural and industrial sites);

- learners with printed materials;

- learners by communication at different levels;

- learning by doing;

- attending public (collective, full-time) forms of education (lectures, seminars, performances in parks, cafes, museums, master classes, workshops, workshops, ateliers).

Components of the educational process in PIE - an informal model:

- Cognitive component: I know and I can.

- Pedagogical component: learning and creating.

- Activity component: I want and I do.

- Management component: manage and execute.

- Innovative component: discover and apply.

- Axiological component: I understand and appreciate.

- Philosophical component: I and Will.

Sections of PIE:

- History of informal education.

- Folk pedagogy. 
- Pedagogy of self-development.

- Pedagogy of experience (lifelong).

- Pedagogy of free time (Popov 2009).

- Home (family) pedagogy (Popov 2006, 44).

- Pedagogy of informal educators (relatives, friends, colleagues, etc.) general scientific, general theoretical, psychological and pedagogical training. Informal educators will be presented in a separate article.

Pedagogical "family" of PIE as transpedagogy:

- PIE is closely related to general pedagogy and its branches: foundations of pedagogy (foundations of PIE); learning theory (autodidactics), education theory (self-education), upbringing theory (self-upbringing).

- Of the teaching methods, PIE directly uses the adult learning methodology (self-study).

- From age-related pedagogy, PIE uses the resources of family pedagogy, andragogy and acmeology (from gr. Akme - "patterns and mechanisms of human development at the stage of his maturity when he reaches the highest level in this development" (Acmeology 2006, 7 - 8)).

- Of the new sectoral pedagogy, PIE is directly related to social pedagogy.

- From the frontier pedagogical sciences, PIE is related to pedagogical valeology (healthy lifestyle).

- From the pedagogy of the new millennium, PIE has a direct connection with:

- heutagogy (Hase 2000) - how to study independently in the XXI century through discoveries, inventions, conclusions, findings;

- pedagogy of free time (Popov 2009);

- pedagogy of leisure;

- the direction of educational technologies: museum pedagogy, theater pedagogy, film pedagogy, art pedagogy, literary pedagogy" (Shastina 2018, $861-862)$

- energy-informational pedagogy (Podlasii 2010).

\section{Conclusion}

The schematic representation of PIE is dictated by the limited volume of a scientific article, but it is enough to open a huge field for research work of many scientists from a wide range of sciences. This is a difficult path of selftransformation from the surviving Homo sapiens (Harari 2015) through Homo faber (from Lat. - "Man producing") (Frisch 1957), Homo ludens (from Lat. "Man playing") (Huizinga 1938) to Homo creabilis (from Lat. - "Self-creating man") (Zhelyazkova-Teya 2015).

Further theoretical work of the author will be associated with the development of PIE. 
To implement the research results, the scientific direction of the Institute for Informal Innovation Foundation, which was created by the author in 2010 in the Republic of Bulgaria will continue to work.

\section{ACKNOWLEDGEMENTS}

The author thanks all scientists, lawyers, administrators, colleagues and friends in the country and abroad, who with their professionalism, optimism and some skepticism helped the emergence of the new Pedagogy of Informal Education.

\section{NOTES}

1. Zhelyazkova (Teya), T., 2010. Informalnoto obrazovanie kato znachim element ot obrazovatelnata triada. Strategii na obrazovatelnata i nauchnata politika, 18(2), 164 - 180 [In Bulgarian].

2. Zhelyazkova (Teya), T., 2010. Obrazovatelnata piramida. In: Inovacii v obuchenieto i poznavatelnoto razvitie. Obrazovanie i tehnologii. 1 [In Bulgarian].

3. Zhelyazkova-Teya, T., 2010. Informalnoto obrazovanie - neobhodim instrument v obshhestvoto na znanieto. In: Obshhestvo na znanieto i humanizmat na XXI vek. Osma nacionalna nauchna konferencija s mezhdunarodno uchastie. Sofia, 540 - 548 [In Bulgarian].

4. Zhelyazkova-Teya, T., 2014. Informalno obrazovanie ili samostoyatelno uchene? Nauka, (1). Sofia: SUB, 68 - 72 [In Bulgarian].

5. Zhelyazkova (Teya), T., 2015. Informalnoto obrazovanie - kljuch kam inkluzivnata obrazovatelna sreda. In: Teorija i praktika na psihologopedagogicheskata podgotovka na specialista v universiteta. Sbornik s nauchni dokladi. Parva kniga. Tom vtori, 274 - 279 [In Bulgarian].

6. Zhelyazkova-Teya, T., 2016. Informalnoto uchene - neizvestno za izvestnoto. In: $\mathrm{V}$ Esenen nauchno-obrazovatelen forum "Savremennoto uchilishhe $\mathrm{i}$ kvalifikacijata na uchitelite". Sofia: SU [DIUU], 25 - 33 [In Bulgarian].

7. Zhelyazkova-Teya T. K., 2018. Modeli differenciacii formal'nogo, neformal'nogo i informal'nogo obrazovanija. Pedagogika i psihologija obrazovanija, (4). Moskva: MPGU, 20 - 36 [In Russian].

8. Zhelyazkova-Teya T. K., 2019. Samorazvitieto na vazrastnite chrez informalnoto uchene prez celija zhivot. In: Vzaimodejstvie na prepodavatelja i studenta $\mathrm{v}$ uslovijata na universitetskoto obrazovanie: teorii, tehnologii, upravlenie. Sbornik s nauchni dokladi /Treta kniga/. Sofia: EKS-PRESS, 483 - 488 [In Bulgarian].

9. CR, 2012. Council Recommendation of 20 December 2012 on the validation of non-formal and informal learning (2012/C 398/01).

10. IO, 2020. Indikatory obrazovanija: 2020: statisticheskij sbornik. Moskva: NIU VShJe, 496 [In Russian]. 


\section{REFERENCES}

ABULHANOVA-SLAVSKAJA, K. A. et al., 2018. Obshhie podhody k izucheniju lichnosti. Pedagogika i psihologija obrazovanija, (4), 178 - 190 [In Russian].

ANDREEV, V.I., 2012. Pedagogika: Uchebnyj kurs dlja tvorcheskogo samorazvitija. Kazan: Centr innovacionnyh tehnologij [In Russian].

DERKACH, A. (ed.), 2004. Akmeologija. Moskva: RAGS [In Russian].

DOCENKO, I. G., 2016. Zakony informal'nogo obrazovanija v obrazovanii professional'nom. In: Formirovanie kadrovogo potenciala SPO - innovacionnye processy na proizvodstve $i v$ professional'nom obrazovanii: Ekaterinburg: RGPPU, 154 - 158 [In Russian].

FRISCH, M., 1957. Homo faber. Bibliothek Suhrkamp.

HASE, S. \& Kenyon, C., 2000. From Andragogy to Heutagogy. Lismore, Australia: Southern Cross University.

HARARI, YUVAL NOAH, 2015. Sapiens: A Brief History of Humankind. London: Vintage Books.

HUIZINGA, J., 1938. Homo Ludens. New York: Random House.

HUTORSKOJ, A. V., 2003. Didakticheskaja Jevristika. Teorija $i$ tehnologija kreativnogo obuchenija. Moskva: MGU [In Russian].

MAKARENKO, A.S., 1983. Pedagogicheskie sochinenija. Moskva: Pedagogika [In Russian].

MAKARENKO, A.S., 1990. O vospitanii. Moskva: Izdatelstvo politicheskoj literatury [In Russian].

NEFEDOVA, G. M., 2017. Formal'noe, neformal'noe i informal'noe obrazovanie: differenciacija ponjatij. Municipalnoe obrazovanie: innovacii i jeksperiment, (3), 73 - 76 [In Russian].

OKERESHKO, A.V., 2015. Vidy informal'nogo obrazovanija kak smysloobrazujushhie faktory lichnostno-professional'nogo razvitija uchitelja. Chelovek i obrazovanie. 42(1), 74 - 78 [In Russian].

PODLASYj, I. P., 2010. Jenergoinformacionnaja pedagogika. Moskva: Data Skver [In Russian].

POPOV, L., 2006. Otrazhenijata na pedagogicheskata realnost. Obshha pedagogika. Sofia: Daniela Ubenova [In Bulgarian].

Popov, L., 2009. Pedagogika na svobodnoto vreme $v$ sistemata na pedagogicheskoto znanie. Izbrani lekcii po pedagogika na svobodnoto vreme. Sofia: Kolbis [In Bulgarian].

POPOV, L., 2009. Velichina, struktura i sadarzhanie na svobodnoto vreme. Sofia: Kolbis [In Bulgarian].

POPOV, L., 2009. Obshha harakteristika na bjudzheta na vremeto i na svobodnoto vreme kato javlenie. Sofia: Kolbis [In Bulgarian]. 
POPOV, L., 2009. Svobodnoto vreme v konteksta na kalendarnoto vreme. Sofia: Kolbis [In Bulgarian].

SLASTENIN, V. A. et al., 2002. Pedagogika. Saratov [In Russian].

SHASTINA, E.M. et al., 2018. Innovacionnye vidy pedagogiki v neformal'nom i informalnom obrazovanii. Alleja nauki, 1(7), 859 - 862 [In Russian].

ZHELYAZKOVA-TEYA, T., 2015. Selection of New Homo Creabilis. The choice between formal, non-formal and informal. Filosofiya-Philosophy, 24(3), 321 - 328 [In Bulgarian].

ZHELYAZKOVA-TEYA, T. K., 2020. Chto govorjat indikatory informal'nogo obrazovanija o ego roli dlja vzroslyh $\mathrm{v}$ novom veke. Vysshee obrazovanie segodnja, 8, 47 - 51 [In Russian].

$\triangle$ Dr. Tanya Zhelyazkova-Teya

Web of Science Researcher ID: AAK-8548-2020

Institute of Informal Innovation

Sofia, Bulgaria

E-mail: teya@iii-bg.org 